\title{
Model Pengukuran Tingkat Kepuasan Masyarakat Terhadap Penggunaan Jasa Transportasi Online di Wilayah Cirebon dengan Metode Fuzzy Servqual
}

\author{
Nursaka Putra ${ }^{1}$, Ilwan Syafrinal ${ }^{2}$, Marsani Asfi ${ }^{3}$ \\ 1,2,3 Fakultas Teknologi dan Informasi, Universitas Catur Insan Cendekia, Cirebon, 45133 \\ 1ursaka.putra@cic.ac.id \\ 2ilwansynl@gmail.com \\ 3.marsani.asfi@gmail.com
}

Received: $15 / 11 / 2020$.

Reviewed: 06/12/2020.

Published: 31/12/2020.

Copyright $\odot 2020$ by the author (et al) and Jurnal Sosial Humaniora (JSH)

*This work is licensed under the Creative

Commons Attribution International License $(\mathrm{CC}$

BY 4.0).

http://creativecommons.org/licenses/by/4.0/

\begin{abstract}
Subject Area: Social Statistics
Abstract

Online transportation responds to people's needs in relation to public transport. Online transportation, which in this context is Grab and Go-Jek, is an alternative that is favored by many people, especially in the Cirebon area. This study aims to measure the level of service satisfaction received and future customer expectations of online transportation services. For our purpose, we use Fuzzy Service Quality method which is used to determine the variable customer needs that are not met by calculating the GAP between the services provided and the expectations of the customer as the Voice of Customer, where the data collection technique is carried out by distributing questionnaires. The results are Reliability rank 2 with a value of 0.100, Responsiveness rank 4 with a value of 0.86, Assurance rank 3 with a value of 0.090, Empathy rank 5 with a value of 0.040, Tangibles rank 1 with a value of 0.139. Based on these results, we suggest that an empathy-related policymaking concerning professionalism should not become an obstacle.
\end{abstract}

Keywords: Online Transportation; Fuzzy Servqual; Gap; Satisfaction

\section{Pendahuluan}

Transportasi merupakan peranan sangat penting dalam kehidupan masyarakat. Transportasi adalah perpindahan manusia atau barang dari satu tempat ketempat lain dengan menggunakan sebuah kendaraan yang digerakkan oleh mesin atau manusia. Transportasi digunakan untuk memudahkan manusia dalam melakukan aktivitas sehari-hari. Transportasi terbagi menjadi tiga bagian, yaitu: jalur darat, jalur laut dan jalur udara. Ketergantungan masyarakat tehadap transportasi sangat tinggi, dengan alasan untuk mempersingkat waktu perjalanan. Didalam transportasi terdapat unsur-unsur yang terkait erat dalam berjalannya konsep transportasi itu sendiri, unsur-unsur tersebut adalah manusia yang membutuhkan, barang yang dibutuhkan, kendaraan sebagai alat, jalan dan terminal sebagai prasarana transportasi, organisasi (pengelola transportasi tersebut). Kemajuan yang sangat pesat dibidang teknologi informasi memberikan pengaruh yang besar terhadap berbagai aspek kehidupan manusia. Pengaruh yang paling nyata terlihat pada perubahan mendasar terhadap cara orang melakukan transaksi, terutama dalam dunia bisnis. Salah satu bisnis yang sedang berkembang saat ini adalah bisnis jasa transportasi online. Penelitian 
mengenai transportasi online diantaranya oleh (Yunus et al., 2019) untuk sistem kerja aplikasi transportasi online dalam peningkatan kinerja driver, oleh (Azizah \& Adawia, 2018) untuk analisis perkembangan industri transportasi online di era inovasi disruptif, oleh (Fajar Nugraha, Zulfadhli, 2020) untuk menganalisa dampak perkembangan industri transportasi online terhadap sosial ekonomi pengemudinya, oleh (Arifin, 2011) untuk menganalisa dampak keberadaan transportasi online terhadap kondisi sosial ekonomi transportasi konvesional di kota Kediri, oleh (Fakhriyah, 2020) untuk menganalisa pengaruh layanan transportasi online (gojek) terhadap perluasan lapangan kerja bagi masyarakat di kota Cimahi dan masih banyak penelitian lainnya.

Seiring berkembangnya teknologi dan informasi di era globalisasi ini telah menimbulkan perubahan yang cukup signifikan akan persaingan usaha pada setiap perusahaan. Sebagai penyedia jasa, perusahaan ojek online harus mampu mempertahankan kualitas pelayanan terhadap pelanggan untuk memberikan dampak positif khususnya di wilayah Cirebon. Mengingat begitu penting suatu pelayanan bidang jasa yang akan mempengaruhi kuantitas pelanggannya sehingga bisnis dapat terus berjalan. Penilaian kualitas pelayanan sangat penting sehingga dapat membantu bisnis dalam usaha peningkatan kualitas pelayanan yang lebih baik dimasa yang akan datang. Berawal dari banyaknya jasa transportasi yang bermunculan mengakibatkan semakin kuat pula persaingan yang dihadapi oleh para pengemudi ojek.

Hampir disetiap sudut jalan besar di wilayah Cirebon banyak ditemui para pengemudi ini. Apabila dicermati ada banyak hal yang harus dibenahi dalam layanan ojek yang ada saat ini khususnya masalah keselamatan, kesopanan dan kewajaran harga layanan. Kehadiran jasa transportasi berbasis online yang terhubung menggunakan internet sangat berpengaruh bagi masyarakat dalam menjalankan segala aktivitas secara cepat dan efisien. Supaya dapat terus berkembang dan dapat bersaing, transportasi online perlu memberikan pelayanan yang terbaik kepada pelanggan. Untuk mengukur kualitas pelayanan pada penelitian ini menggunakan metode Fuzzy Service Quality. Metode ini banyak digunakan sebagai metode untuk mengukur kualitas pelayanan, adapun penelitian tersebut adalah seperti berikut: menganalisa kepuasan pelayanan pendidikan pada jurusan ilmu komputer Fakultas Sains dan Teknik Universitas Nusa Cendana yang diteliti oleh (Ligoresi et al., 2017), analisis kepuasan pelanggan travel oleh (Sholikah \& Iriananda, 2017), terhadap tingkat kepuasan layanan mahasiswa oleh (Kartika, 2017), analisis kualitas pelayanan pada kantor pos pusat kota Padang oleh (Widia Afriyuni, Rahmiati, 2019), analisis kualitas pelayanan publik oleh (Widyarto et al., 2018) serta masih banyak penelitian lainnya.

Metode Fuzzy Service Quality yang digunakan adalah untuk melihat seberapa jauh perbedaan antara harapan atau ekspektasi dan kinerja atau persepsi pelanggan atas pelayanan yang mereka rasakan pada perusahaan jasa transportasi online dalam konteks ini adalah Grab dan Go-Jek, dimana teknik pengumpulan data dilakukan dengan penyebaran kuesioner kepada pengguna aplikasi tersebut.

\section{Tinjauan Pustaka}

Kualitas jasa adalah tingkat keunggulan yang diharapkan dan pengendalian atas tingkat keunggulan tersebut untuk memenuhi keinginan pelanggan. Dengan kata lain ada dua faktor utama yang mempengaruhi 
kualitas jasa, yaitu Expected Service dan Perceived Service. Apabila jasa yang diterima atau dirasakan (perceived service) sesuai dengan yang diharapkan, maka kuliatas jasa dipersepsikan sebagai kualitas yang ideal. Sebaliknya jika jasa yang diterima lebih rendah daripada yang diharapkan, maka kualitas jasa dipersepsikan buruk. Dengan demikian baik tidaknya kualitas jasa tergantung pada kemampuan penyedia jasa dalam memenuhi harapan pelanggannya secara konsisten (Rimawati, 2016).

Ada beberapa pendapat mengenai dimensi kualitas pelayanan, antara lain Parasuraman, Zeithaml dan Berry (2010:103) yang melakukan penelitian khusus terhadap beberapa jenis jasa dan berhasil mengidentifikasi sepuluh faktor utama yang menentukan kualitas jasa. Kesepuluh faktor tersebut adalah:

a. Reliability mencakup dua hal pokok, yaitu konsistensi kerja (perfomance) dan kemampuan untuk dipercaya (dependbility). Hal ini berarti perusahaan memberikan jasanya secara tepat semenjak saat pertama. Selain itu juga berarti perusahaan yang bersangkutan memenuhi janjinya, misalnya menyampaikan jasanya sesuai dengan jadwal yang disepakati.

b. Responsiveness, yaitu kemampuan atau kesiapan para karyawan untuk memberikan jasa yang dibutuhkan pelanggan.

c. Competence artinya setiap orang dalam suatu perusahaan memiliki keterampilan dan pengetahuan yang dibutuhkan agar dapat memberikan jasa tertentu.

d. Accessibility meliputi kemudahan untuk menghubungi dan ditemui. Hal ini berarti lokasi fasilitas jasa yang mudah dijangkau, waktu menunggu yang tidak terlalu lama, saluran komunikasi perusahaan mudah dihubungi dan lain-lain.

e. Courtesy, meliputi sifat sopan santun, respek, perhatian dan keramahan yang dimiliki para kontak personal.

f. Communication artinya memberikan informasi kepada pelanggan pada bahasa yang dapat mereka pahami, serta selalu mendengar saran dan keluhan pelanggan.

g. Credibility yaitu sifat jujur dan dapat dipercaya. Kredibilitas mencakup nama perusahaan, reputasi perusahaan, karakteristik pribadi kontak personal dan interaksi dengan pelanggan.

h. Security yaitu aman dari bahaya, resiko atau keragu-raguan. Aspek ini meliputi keamanan secara fisik (Physical Safety), keamanan finansial (Financial Security) dan kerahasiaan (Confidentiality).

i. Understanding/Knowing the Customer yaitu usaha untuk memahami kebutuhan pelanggan.

j. Tangibles yaitu bukti fisik dari jasa, bisa berupa fasilitas fisik, peralatan yang dipergunakan atau penampilan dari personaliti.

\section{Metode Penelitian}

Tahapan penelitian untuk menganalisis tingkat kepuasan masyarakat terhadap pelayanan jasa transportasi online ini secara umum dilihat pada gambar 1. 
Gambar 1. Kerangka Penelitian

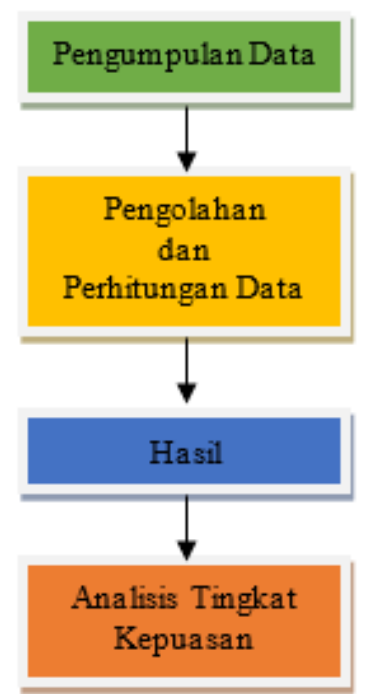

Berdasarkan penelitian yang dilakukan, maka dapat dilihat diagram alir penelitian pada gambar 2 . berikut:

Gambar 2. Diagram Alir Penelitian

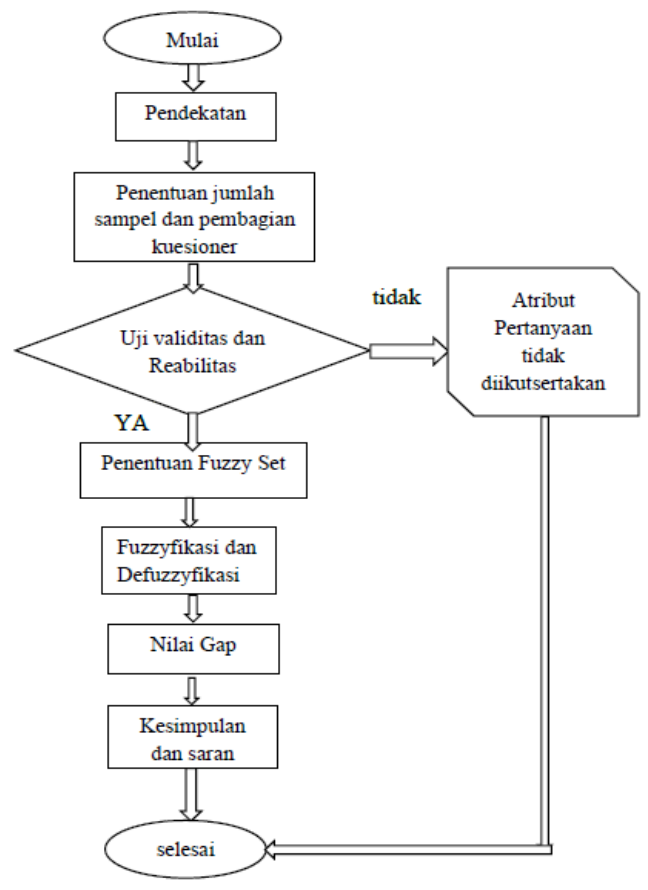

Metode yang digunakan pada penelitian ini adalah metode Fuzzy Servqual yang digunakan untuk model pengukuran tingkat kepuasan masyarakat terhadap penggunaan jasa transportasi online di wilayah Cirebon. Adapun data yang digunakan berupa hasil kuesioner yang diambil melalui Google Form. Berikut adalah pertanyaan yang digunakan.

\section{Hasil Penelitian dan Pembahasan}

Tabel 1. Kuesioner

\section{RELIABILITY}

No $\quad$ Pertanyaan

1 Pengendara Ojek Online cepat tanggap dalam melayani pesanan pelanggan 


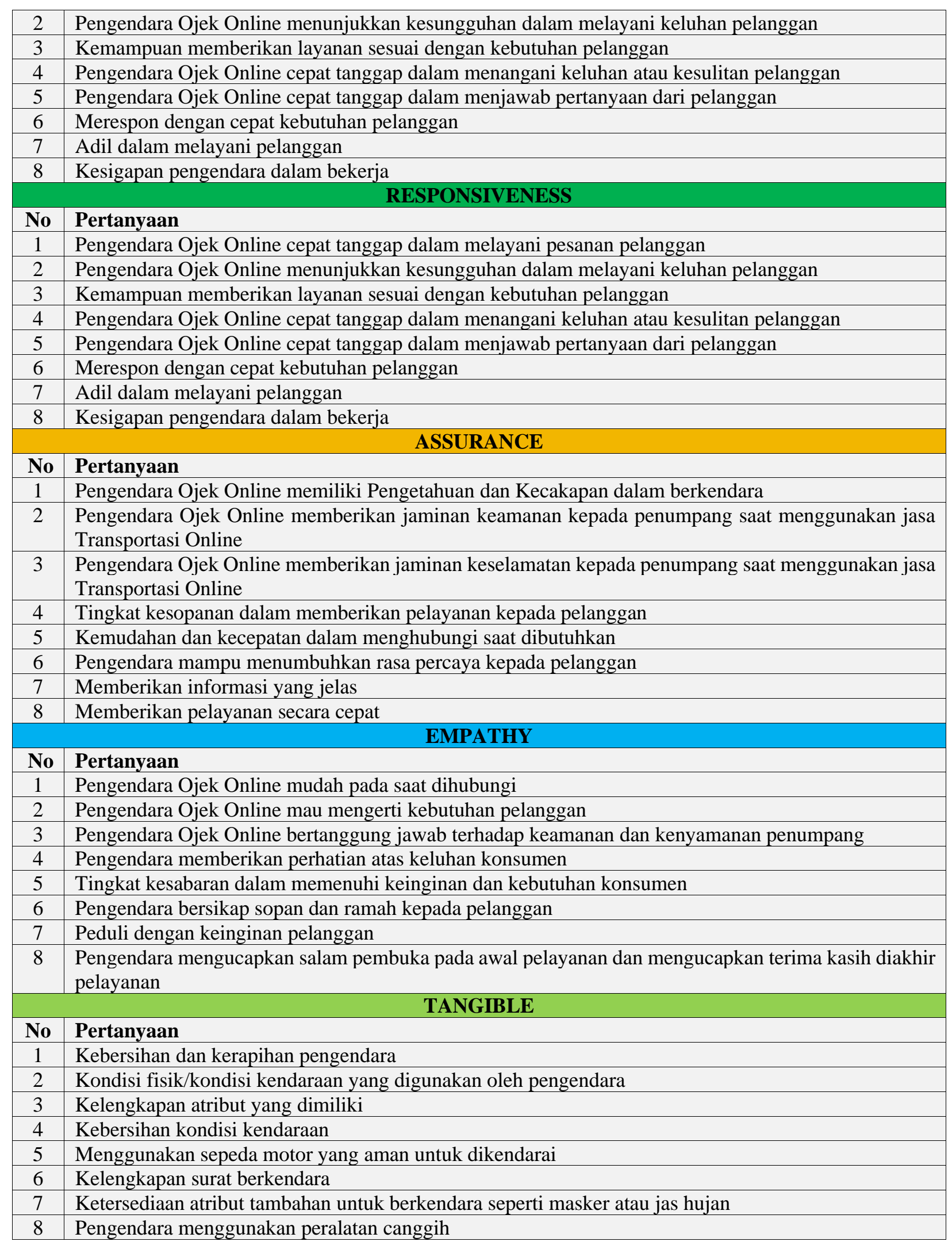

Selanjutnya akan dibentuk nilai Mean dan GAP pada masing-masing kriteria dan juga pertanyaan pada kuesioner seperti tabel 2. 
Tabel 2. Mean dan GAP

\begin{tabular}{|c|c|c|c|}
\hline RELIABILITY & \multicolumn{2}{|c|}{ MEAN } & \multirow{2}{*}{ GAP } \\
\hline No. Pertanyaan & HARAPAN & PERSEPSI & \\
\hline 1 & 4,26 & 4,26 & 0 \\
\hline 2 & 4,26 & 4,12 & $-0,14$ \\
\hline 3 & 4,26 & 4,24 & $-0,02$ \\
\hline 4 & 4,26 & 4,02 & $-0,24$ \\
\hline 5 & 4,26 & 4,14 & $-0,12$ \\
\hline 6 & 4,26 & 4,2 & $-0,06$ \\
\hline 7 & 4,26 & 4,12 & $-0,14$ \\
\hline 8 & 4,26 & 4,18 & $-0,08$ \\
\hline RESPONSIVENESS & \multicolumn{2}{|c|}{ MEAN } & \multirow{2}{*}{ GAP } \\
\hline No. Pertanyaan & HARAPAN & PERSEPSI & \\
\hline 1 & 4,23 & 4,23 & 0 \\
\hline 2 & 4,23 & 4,15 & $-0,08$ \\
\hline 3 & 4,23 & 4,14 & $-0,09$ \\
\hline 4 & 4,23 & 4,04 & $-0,19$ \\
\hline 5 & 4,23 & 4,16 & $-0,07$ \\
\hline 6 & 4,23 & 4,09 & $-0,14$ \\
\hline 7 & 4,23 & 4,19 & $-0,04$ \\
\hline 8 & 4,23 & 4,17 & $-0,06$ \\
\hline ASSURANCE & \multicolumn{2}{|c|}{ MEAN } & \multirow{2}{*}{ GAP } \\
\hline No. Pertanyaan & HARAPAN & PERSEPSI & \\
\hline 1 & 4,25 & 4,14 & $-0,11$ \\
\hline 2 & 4,25 & 4,09 & $-0,16$ \\
\hline 3 & 4,25 & 4,14 & $-0,11$ \\
\hline 4 & 4,25 & 4,2 & $-0,05$ \\
\hline 5 & 4,25 & 4,16 & $-0,09$ \\
\hline 6 & 4,25 & 4,12 & $-0,13$ \\
\hline 7 & 4,25 & 4,25 & 0 \\
\hline 8 & 4,25 & 4,18 & $-0,07$ \\
\hline EMPATHY & \multicolumn{2}{|c|}{ MEAN } & \multirow{2}{*}{ GAP } \\
\hline No. Pertanyaan & HARAPAN & PERSEPSI & \\
\hline 1 & 4,22 & 4,17 & $-0,05$ \\
\hline 2 & 4,22 & 4,13 & $-0,09$ \\
\hline 3 & 4,22 & 4,22 & 0 \\
\hline 4 & 4,22 & 4,12 & $-0,1$ \\
\hline 5 & 4,22 & 4,2 & $-0,02$ \\
\hline 6 & 4,22 & 4,2 & $-0,02$ \\
\hline 7 & 4,22 & 4,17 & $-0,05$ \\
\hline 8 & 4,22 & 4,19 & $-0,03$ \\
\hline TANGIBLE & \multicolumn{2}{|c|}{ MEAN } & \multirow{2}{*}{ GAP } \\
\hline No. Pertanyaan & HARAPAN & PERSEPSI & \\
\hline 1 & 4,29 & 4,04 & $-0,25$ \\
\hline 2 & 4,29 & 4,13 & $-0,16$ \\
\hline 3 & 4,29 & 4,15 & $-0,14$ \\
\hline 4 & 4,29 & 4,12 & $-0,17$ \\
\hline 5 & 4,29 & 4,29 & 0 \\
\hline 6 & 4,29 & 4,28 & $-0,01$ \\
\hline 7 & 4,29 & 4,1 & $-0,19$ \\
\hline 8 & 4,29 & 3,9 & $-0,39$ \\
\hline
\end{tabular}




\section{Hasil Penelitian dan Pembahasan}

Pada penelitian ini, digunakan 100 orang responden sebagai data yang akan diolah nantinya dengan menggunakan metode Fuzzy Servqual, berikut hasil kuesioner yang didapatkan yang ditampilkan pada tabel 3 .

Tabel 3. Data Kuesioner

\begin{tabular}{|c|c|c|c|c|c|c|c|c|c|c|c|c|c|c|c|c|c|c|}
\hline No & & Reliability & & & & sp & on: & siv & en & & & & ssuranc & & & Empathy & Tangible & Rata-Rata \\
\hline 1 & 5 & \begin{tabular}{l|l|l|l|l|l}
5 & 5 & 4 & 4 & 5 & 5 \\
\end{tabular} & & 5 & 5 & 5 & 4 & 4 & 4 & 3 & $4:$ & & \begin{tabular}{l|l|l|l}
5 & 5 & 4 & 4 \\
\end{tabular} & & & \begin{tabular}{|l|l|l|l|l|l}
5 & 5 & 5 & 5 & 5 & 5
\end{tabular} & \begin{tabular}{|l|l|l|l|l|l|l|l|l|}
5 & 4 & 4 & 4 & 4 & 4 & 3 & 4 & 3 \\
\end{tabular} & 4,475 \\
\hline 2 & 4 & \begin{tabular}{|l|l|l|l|l|}
4 & 5 & 4 & 4 & 5 \\
\end{tabular} & 44 & 5 & 4 & 4 & 4 & 4 & 4 & 4 & 4 & \begin{tabular}{ll|}
44 \\
\end{tabular} & \begin{tabular}{l|l|l|l}
4 & 4 & 4 & 4 \\
\end{tabular} & 44 & 44 & \begin{tabular}{l|l|l|l|l|l|l|l|l|l|l|l|l|l|l|l}
4 & 4 & 4 & 4
\end{tabular} & 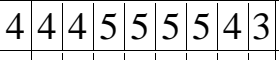 & 4,15 \\
\hline 3 & 4 & \begin{tabular}{l|l|l|l|l|}
4 & 4 & 4 & 4 & 4
\end{tabular} & & 4 & 4 & 4 & 4 & 4 & 4 & 4 & 4 & \begin{tabular}{|l|l|}
4 & 4 \\
\end{tabular} & \begin{tabular}{l|l|l|l}
4 & 4 & 4 & 4 \\
\end{tabular} & 44 & 44 & \begin{tabular}{|l|l|l|l|l|l|l|l|l|l|l|l|l|l|l|l}
4 & 4 & 4 & 4
\end{tabular} & 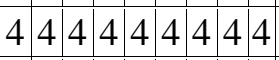 & 4 \\
\hline 4 & 4 & \begin{tabular}{|l|l|l|l|l|l|l|}
4 & 4 & 4 & 4 & 4 \\
\end{tabular} & 44 & 4 & 4 & 4 & 4 & 4 & 4 & 4 & 4 & \begin{tabular}{|l|l|}
4 & 4 \\
\end{tabular} & \begin{tabular}{l|l|l|l}
4 & 4 & 4 & 4 \\
\end{tabular} & 44 & 44 & 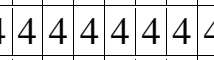 & 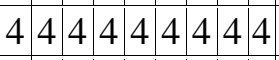 & 4 \\
\hline 5 & 5 & \begin{tabular}{|l|l|l|l|l|}
2 & 3 & 5 & 2 & 1 \\
\end{tabular} & 14 & 4 & 4 & 2 & 4 & 4 & 3 & 4 & 4 & \begin{tabular}{|l|l|}
4 & 5 \\
\end{tabular} & \begin{tabular}{l|l|l|l}
5 & 5 & 3 & 4 \\
\end{tabular} & & $\begin{array}{ll}3 & 4 \\
\end{array}$ & \begin{tabular}{|l|l|l|l|l|l|l|l|l|l|l|l|l|l|l|l|l} 
& 4 & 3
\end{tabular} & 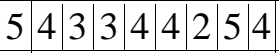 & 3,575 \\
\hline 6 & 5 & \begin{tabular}{l|l|l|l|l|l}
4 & 5 & 4 & 4 & 5 & \\
\end{tabular} & \begin{tabular}{l|l}
44 \\
\end{tabular} & 4 & 4 & 4 & 4 & 4 & 4 & 4 & 4 & $4 \mid 4$ & \begin{tabular}{l|l|l|l}
4 & 3 & 4 & 4 \\
\end{tabular} & 42 & 44 & \begin{tabular}{|l|l|l|l|l|l|l|l|l|l|l|l|l|l|l|l}
4 & 4 & 4 & 4
\end{tabular} & \begin{tabular}{|l|l|l|l|l|l|l|l|l|}
4 & 3 & 4 & 4 & 4 & 4 & 4 & 4 & 4 \\
\end{tabular} & 4 \\
\hline 7 & 5 & $555555:$ & 55 & 5 & 5 & 5 & 5 & 5 & 5 & 5 & 5 & 55 & 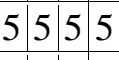 & 55 & & \begin{tabular}{l|l|l|l|l|l|l|l|l|l|l}
5 & 5 & 5 & 5 & 5 & 5
\end{tabular} & \begin{tabular}{|l|l|l|l|l|l|l|l|}
5 & 5 & 5 & 5 & 5 & 5 & 5 & 5 \\
\end{tabular} & 5 \\
\hline 8 & 4 & \begin{tabular}{l|l|l|l|l|l|}
4 & 4 & 4 & 4 & 5 \\
\end{tabular} & \begin{tabular}{l|l}
44 \\
\end{tabular} & 4 & 4 & 4 & 4 & 4 & 5 & 4 & 4 & $4 \mid 4$ & \begin{tabular}{l|l|l|l}
4 & 5 & 5 & 4 \\
\end{tabular} & 52 & 44 & \begin{tabular}{|l|l|l|l|l|l|l|l|l|l|l|l|l|l|l|l}
4 & 4 & 4 & 4
\end{tabular} & 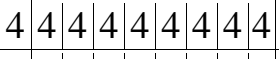 & 4,125 \\
\hline 9 & 4 & \begin{tabular}{l|l|l|l|l|l}
3 & 4 & 3 & 4 & 4 & 3
\end{tabular} & 33 & 4 & 3 & 3 & 3 & 3 & 3 & 3 & 3 & $4 \mid 4$ & 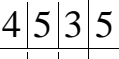 & 55 & & 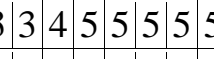 & 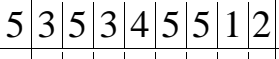 & 3,775 \\
\hline 10 & 4 & \begin{tabular}{|l|l|l|l|l|}
5 & 5 & 5 & 4 & 4 \\
\end{tabular} & 45 & & 5 & 5 & 4 & 5 & 4 & 5 & 4 & \begin{tabular}{|l|l|}
5 & 5 \\
\end{tabular} & 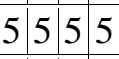 & 55 & 54 & 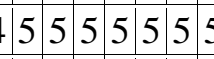 & 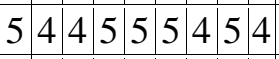 & 4,675 \\
\hline & & & $\cdot$ & & & & & & & & & $\cdot$ & .1 .1$. & $\cdot$ & $\cdot$ & . . . . . . &...$+|\cdot.| \cdot$. & $\cdot$ \\
\hline & $\cdot$ & $. .1 . .1$. &. . & & & . & & & & & . &. &.. .2. & & . $\cdot$ & ........ & ........... & . \\
\hline 100 & 3 & \begin{tabular}{|l|l|l|l|l|l|l|l|}
4 & 4 & 3 & 4 & 4
\end{tabular} & & & 4 & 4 & 4 & 3 & & 4 & & & \begin{tabular}{l|l|l|l}
4 & 4 & 4 & 4 \\
\end{tabular} & $4<$ & & 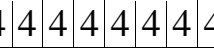 & 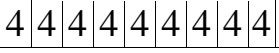 & 3,9 \\
\hline
\end{tabular}

Selanjutnya akan dicari nilai rata-rata setiap pertanyaan dari 100 responden yang akan ditampilkan pada tabel 4 .

Tabel 4. Rata-Rata Nilai Pertanyaan

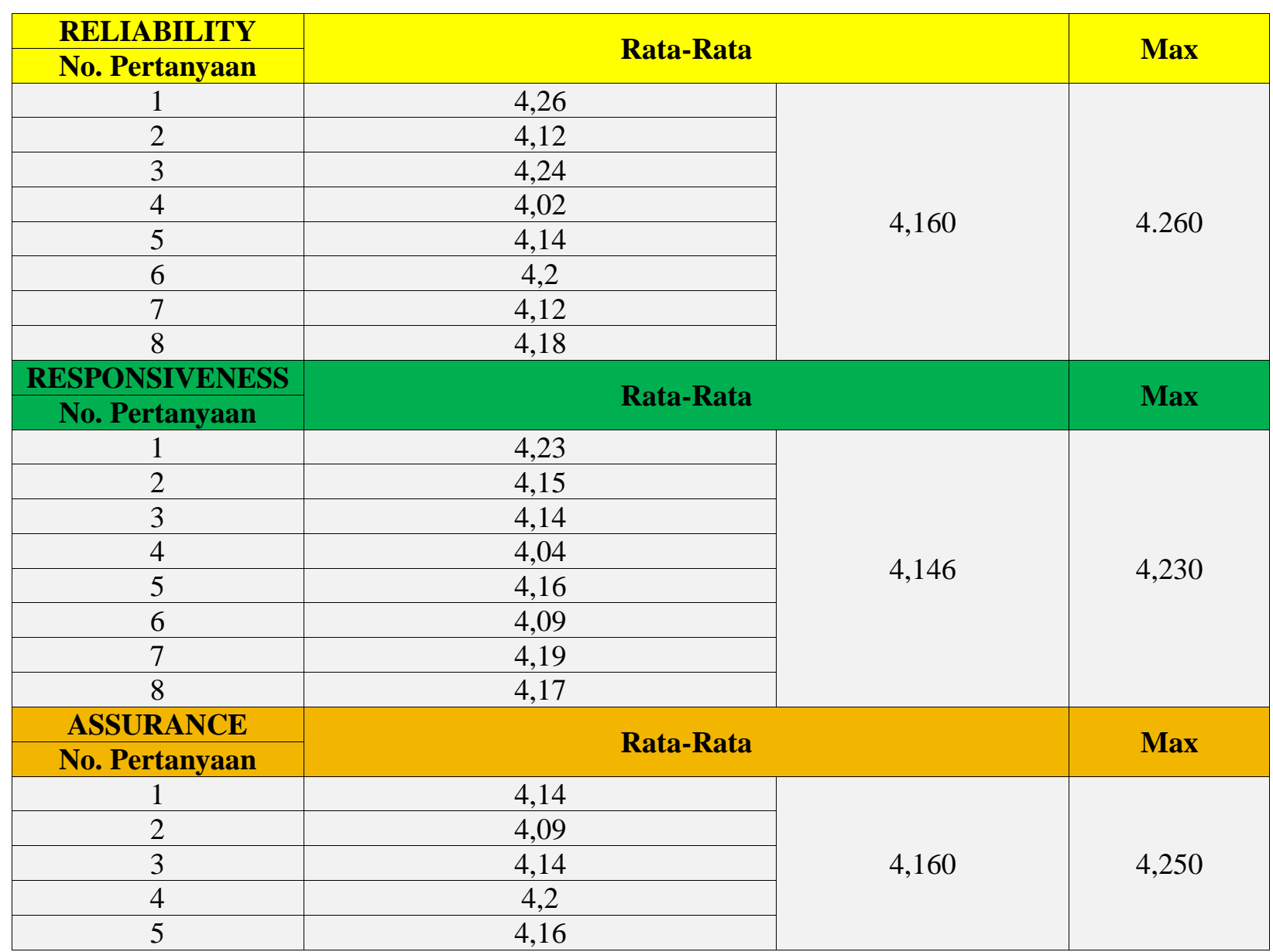




\begin{tabular}{|c|c|c|c|}
\hline 6 & 4,12 & & \\
\hline 7 & 4,25 & & \\
\hline 8 & 4,18 & & \\
\hline EMPATHY & \multirow{2}{*}{\multicolumn{2}{|c|}{ Rata-Rata }} & \multirow{2}{*}{$\operatorname{Max}$} \\
\hline No. Pertanyaan & & & \\
\hline 1 & 4,17 & \multirow{8}{*}{4,175} & \multirow{8}{*}{4,220} \\
\hline 2 & 4,13 & & \\
\hline 3 & 4,22 & & \\
\hline 4 & 4,12 & & \\
\hline 5 & 4,2 & & \\
\hline 6 & 4,2 & & \\
\hline 7 & 4,17 & & \\
\hline 8 & 4,19 & & \\
\hline TANGIBLE & \multirow{2}{*}{\multicolumn{2}{|c|}{ Rata-Rata }} & \multirow{2}{*}{ Max } \\
\hline No. Pertanyaan & & & \\
\hline 1 & 4,04 & \multirow{8}{*}{4,126} & \multirow{8}{*}{4,290} \\
\hline 2 & 4,13 & & \\
\hline 3 & 4,15 & & \\
\hline 4 & 4,12 & & \\
\hline 5 & 4,29 & & \\
\hline 6 & 4,28 & & \\
\hline 7 & 4,1 & & \\
\hline 8 & 3,9 & & \\
\hline
\end{tabular}

Setelah didapatkan nilai rata-rata dan nilai max setiap indikator penilaian maka akan dicari nilai Fuzzyfikasi pada setiap indikator yang akan ditampilkan pada tabel 5.

Tabel 5. Hasil Fuzzyfikasi Reliability

\begin{tabular}{|c|c|c|c|c|c|c|c|c|}
\hline \multicolumn{9}{|c|}{ Reliability } \\
\hline \multirow{2}{*}{ No } & \multirow{2}{*}{ Pertanyaan } & \multicolumn{2}{|c|}{ Mean } & \multirow{2}{*}{ GAP } & \multicolumn{2}{|c|}{ Fuzzyfikasi } & \multirow{2}{*}{ GAP } & \multirow{2}{*}{ Rangking } \\
\hline & & Harapan & Persepsi & & Harapan & Persepsi & & \\
\hline 1 & item-1 & 4,26 & 4,26 & 0 & 0,74 & 0,74 & 0 & 8 \\
\hline 2 & item-2 & 4,26 & 4,12 & $-0,14$ & 0,74 & 0,88 & 0,14 & 2 \\
\hline 3 & item-3 & 4,26 & 4,24 & $-0,02$ & 0,74 & 0,76 & 0,02 & 7 \\
\hline 4 & item-4 & 4,26 & 4,02 & $-0,24$ & 0,74 & 0,98 & 0,24 & 1 \\
\hline 5 & item-5 & 4,26 & 4,14 & $-0,12$ & 0,74 & 0,86 & 0,12 & 4 \\
\hline 6 & item-6 & 4,26 & 4,2 & $-0,06$ & 0,74 & 0,8 & 0,06 & 6 \\
\hline 7 & item-7 & 4,26 & 4,12 & $-0,14$ & 0,74 & 0,88 & 0,14 & 2 \\
\hline 8 & item- 8 & 4,26 & 4,18 & $-0,08$ & 0,74 & 0,82 & 0,08 & 5 \\
\hline \multicolumn{5}{|c|}{ RATA-RATA } & 0,74 & $\mathbf{0 , 8 4}$ & 0,1 & \\
\hline
\end{tabular}

Tabel 6. Hasil Fuzzyfikasi Responsiveness

\begin{tabular}{|c|l|c|c|c|c|c|c|c|}
\hline \multirow{2}{*}{ No } & \multirow{2}{*}{ Pertanyaan } & \multicolumn{2}{|c|}{ Mean } & \multirow{2}{*}{ GAP } & \multicolumn{2}{c|}{ Fuzzyfikasi } & \multirow{2}{*}{ GAP } & \multirow{2}{*}{ Rangking } \\
\cline { 3 - 4 } & & Harapan & Persepsi & & Harapan & Persepsi & & 0 \\
\hline 1 & item-1 & 4,23 & 4,23 & 0 & 0,77 & 0,77 & 0 & 8 \\
\hline 2 & item-2 & 4,23 & 4,15 & $-0,08$ & 0,77 & 0,85 & 0,08 & 5 \\
\hline 3 & item-3 & 4,23 & 4,14 & $-0,09$ & 0,77 & 0,86 & 0,09 & 3 \\
\hline 4 & item-4 & 4,23 & 4,04 & $-0,19$ & 0,77 & 0,96 & 0,19 & 1 \\
\hline 5 & item-5 & 4,23 & 4,16 & $-0,07$ & 0,77 & 0,86 & 0,09 & 3 \\
\hline 6 & item-6 & 4,23 & 4,09 & $-0,14$ & 0,77 & 0,91 & 0,14 & 2 \\
\hline 7 & item-7 & 4,23 & 4,19 & $-0,04$ & 0,77 & 0,81 & 0,04 & 7 \\
\hline
\end{tabular}




\begin{tabular}{|c|c|c|c|c|c|c|c|c|}
\hline 8 & item-8 & 4,23 & 4,17 & $-0,06$ & 0,77 & 0,83 & 0,06 & 6 \\
\hline \multicolumn{3}{|c|}{ RATA-RATA } & & $\mathbf{0 , 7 7}$ & $\mathbf{0 , 8 5 6 2 5}$ & $\mathbf{0 , 0 8 6 2 5}$ & \\
\hline
\end{tabular}

Tabel 7. Hasil Fuzzyfikasi Assurance

\begin{tabular}{|c|c|c|c|c|c|c|c|c|}
\hline \multicolumn{9}{|c|}{ Assurance } \\
\hline \multirow{2}{*}{ No } & \multirow{2}{*}{ Pertanyaan } & \multicolumn{2}{|c|}{ Mean } & \multirow{2}{*}{ GAP } & \multicolumn{2}{|c|}{ Fuzzyfikasi } & \multirow{2}{*}{ GAP } & \multirow{2}{*}{ Rangking } \\
\hline & & Harapan & Persepsi & & Harapan & Persepsi & & \\
\hline 1 & item-1 & 4,25 & 4,14 & $-0,11$ & 0,75 & 0,86 & 0,11 & 3 \\
\hline 2 & item-2 & 4,25 & 4,09 & $-0,16$ & 0,75 & 0,91 & 0,16 & 1 \\
\hline 3 & item-3 & 4,25 & 4,14 & $-0,11$ & 0,75 & 0,86 & 0,11 & 3 \\
\hline 4 & item-4 & 4,25 & 4,2 & $-0,05$ & 0,75 & 0,8 & 0,05 & 7 \\
\hline 5 & item-5 & 4,25 & 4,16 & $-0,09$ & 0,75 & 0,84 & 0,09 & 5 \\
\hline 6 & item-6 & 4,25 & 4,12 & $-0,13$ & 0,75 & 0,88 & 0,13 & 2 \\
\hline 7 & item-7 & 4,25 & 4,25 & 0 & 0,75 & 0,75 & 0 & 8 \\
\hline 8 & item-8 & 4,25 & 4,18 & $-0,07$ & 0,75 & 0,82 & 0,07 & 6 \\
\hline \multicolumn{5}{|c|}{ RATA-RATA } & $\mathbf{0 , 7 5}$ & $\mathbf{0 , 8 4}$ & 0,09 & \\
\hline
\end{tabular}

Tabel 8. Hasil Fuzzyfikasi Empathy

\begin{tabular}{|c|c|c|c|c|c|c|c|c|}
\hline \multicolumn{9}{|c|}{ Empathy } \\
\hline \multirow{2}{*}{ No } & \multirow{2}{*}{ Pertanyaan } & \multicolumn{2}{|c|}{ Mean } & \multirow{2}{*}{ GAP } & \multicolumn{2}{|c|}{ Fuzzyfikasi } & \multirow{2}{*}{ GAP } & \multirow{2}{*}{ Rangking } \\
\hline & & Harapan & Persepsi & & Harapan & Persepsi & & \\
\hline 1 & item-1 & 4,22 & 4,17 & $-0,05$ & 0,78 & 0,83 & 0,05 & 3 \\
\hline 2 & item-2 & 4,22 & 4,13 & $-0,09$ & 0,78 & 0,87 & 0,09 & 2 \\
\hline 3 & item-3 & 4,22 & 4,22 & 0 & 0,78 & 0,78 & 0 & 6 \\
\hline 4 & item-4 & 4,22 & 4,12 & $-0,1$ & 0,78 & 0,88 & 0,1 & 1 \\
\hline 5 & item-5 & 4,22 & 4,2 & $-0,02$ & 0,78 & 0,78 & 0 & 6 \\
\hline 6 & item-6 & 4,22 & 4,2 & $-0,02$ & 0,78 & 0,78 & 0 & 6 \\
\hline 7 & item-7 & 4,22 & 4,17 & $-0,05$ & 0,78 & 0,83 & 0,05 & 3 \\
\hline 8 & item-8 & 4,22 & 4,19 & $-0,03$ & 0,78 & 0,81 & 0,03 & 5 \\
\hline \multicolumn{5}{|c|}{ RATA-RATA } & 0,78 & $\mathbf{0 , 8 2}$ & 0,04 & \\
\hline
\end{tabular}

Tabel 9. Hasil Fuzzyfikasi Tangible

\begin{tabular}{|c|c|c|c|c|c|c|c|c|}
\hline \multicolumn{9}{|c|}{ Tangible } \\
\hline \multirow{2}{*}{ No } & \multirow{2}{*}{ Pertanyaan } & \multicolumn{2}{|c|}{ Mean } & \multirow{2}{*}{$\begin{array}{c}\text { GA } \\
\mathbf{P}\end{array}$} & \multicolumn{2}{|c|}{ Fuzzyfikasi } & \multirow{2}{*}{ GAP } & \multirow{2}{*}{ Rangking } \\
\hline & & Harapan & Persepsi & & Harapan & Persepsi & & \\
\hline 1 & item-1 & 4,29 & 4,04 & $-0,25$ & 0,71 & 0,96 & 0,25 & 1 \\
\hline 2 & item-2 & 4,29 & 4,13 & $-0,16$ & 0,71 & 0,87 & 0,16 & 5 \\
\hline 3 & item-3 & 4,29 & 4,15 & $-0,14$ & 0,71 & 0,85 & 0,14 & 6 \\
\hline 4 & item-4 & 4,29 & 4,12 & $-0,17$ & 0,71 & 0,88 & 0,17 & 4 \\
\hline 5 & item-5 & 4,29 & 4,29 & 0 & 0,71 & 0,71 & 0 & 8 \\
\hline 6 & item-6 & 4,29 & 4,28 & $-0,01$ & 0,71 & 0,72 & 0,01 & 7 \\
\hline 7 & item-7 & 4,29 & 4,1 & $-0,19$ & 0,71 & 0,9 & 0,19 & 2 \\
\hline 8 & item-8 & 4,29 & 3,9 & $-0,39$ & 0,71 & 0,9 & 0,19 & 2 \\
\hline \multicolumn{5}{|c|}{ RATA-RATA } & 0,71 & 0,84875 & 0,13875 & \\
\hline
\end{tabular}

Perhitungan nilai Service Quality (GAP) per kriteria antara persepsi dan harapan menunjukkan sejauh mana pihak penyedia jasa transportasi ojek online yaitu Grab dan Go-Jek telah memberikan pelayanan sesuai dengan keinginan pelanggan. Peran GAP perkriteria memberikan tingkat kepentingan seberapa jauh 
peran kriteria tersebut dalam memberikan peningkatan kepuasan kepada pelanggan. Hasil dari perhitungan nilai Service Quality (GAP) per kriteria antara persepsi dan harapan dapat dilihat pada tabel 10.

Tabel 10. Nilai Service Quality (GAP)

\begin{tabular}{|c|c|c|c|c|}
\hline \multirow{2}{*}{ No. Pertanyaan } & \multicolumn{2}{|c|}{ MEAN } & \multirow{2}{*}{ GAP } & \multirow{2}{*}{ RANKING } \\
\hline & HARAPAN & PERSEPSI & & \\
\hline 1 & 0,74 & 0,74 & 0 & 38 \\
\hline 2 & 0,74 & 0,88 & $-0,14$ & 8 \\
\hline 3 & 0,74 & 0,76 & $-0,02$ & 36 \\
\hline 4 & 0,74 & 0,98 & $-0,24$ & 1 \\
\hline 5 & 0,74 & 0,86 & $-0,12$ & 15 \\
\hline 6 & 0,74 & 0,8 & $-0,06$ & 30 \\
\hline 7 & 0,74 & 0,88 & $-0,14$ & 8 \\
\hline 8 & 0,74 & 0,82 & $-0,08$ & 26 \\
\hline 1 & 0,74 & 0,77 & $-0,03$ & 35 \\
\hline 2 & 0,74 & 0,85 & $-0,11$ & 20 \\
\hline 3 & 0,74 & 0,86 & $-0,12$ & 15 \\
\hline 4 & 0,74 & 0,96 & $-0,22$ & 2 \\
\hline 5 & 0,74 & 0,86 & $-0,12$ & 15 \\
\hline 6 & 0,74 & 0,91 & $-0,17$ & 4 \\
\hline 7 & 0,74 & 0,81 & $-0,07$ & 28 \\
\hline 8 & 0,74 & 0,83 & $-0,09$ & 23 \\
\hline 1 & 0,74 & 0,86 & $-0,12$ & 15 \\
\hline 2 & 0,74 & 0,91 & $-0,17$ & 4 \\
\hline 3 & 0,74 & 0,86 & $-0,12$ & 15 \\
\hline 4 & 0,74 & 0,8 & $-0,06$ & 30 \\
\hline 5 & 0,74 & 0,84 & $-0,1$ & 22 \\
\hline 6 & 0,74 & 0,88 & $-0,14$ & 8 \\
\hline 7 & 0,74 & 0,75 & $-0,01$ & 37 \\
\hline 8 & 0,74 & 0,82 & $-0,08$ & 26 \\
\hline 1 & 0,74 & 0,83 & $-0,09$ & 23 \\
\hline 2 & 0,74 & 0,87 & $-0,13$ & 13 \\
\hline 3 & 0,74 & 0,78 & $-0,04$ & 32 \\
\hline 4 & 0,74 & 0,88 & $-0,14$ & 8 \\
\hline 5 & 0,74 & 0,78 & $-0,04$ & 32 \\
\hline 6 & 0,74 & 0,78 & $-0,04$ & 32 \\
\hline 7 & 0,74 & 0,83 & $-0,09$ & 23 \\
\hline 8 & 0,74 & 0,81 & $-0,07$ & 28 \\
\hline 1 & 0,74 & 0,96 & $-0,22$ & 2 \\
\hline 2 & 0,74 & 0,87 & $-0,13$ & 13 \\
\hline 3 & 0,74 & 0,85 & $-0,11$ & 20 \\
\hline 4 & 0,74 & 0,88 & $-0,14$ & 8 \\
\hline 5 & 0,74 & 0,71 & 0,03 & 40 \\
\hline 6 & 0,74 & 0,72 & 0,02 & 39 \\
\hline 7 & 0,74 & 0,9 & $-0,16$ & 6 \\
\hline 8 & 0,74 & 0,9 & $-0,16$ & 6 \\
\hline
\end{tabular}

Perhitungan nilai Service Quality (GAP) per dimensi antara persepsi dan harapan menunjukkan sejauh mana pihak penyedia jasa transportasi ojek online yaitu Grab dan Go-Jek telah memberikan pelayanan sesuai dengan keinginan pelanggan. Peran GAP per dimensi memberikan tingkat kepentingan 
seberapa jauh peran kelima dimensi tersebut dalam memberikan peningkatan kepuasan pelayanan. Hasil dari perhitungan nilai Service Quality (GAP) per dimensi antara persepsi dan harapan dapat dilihat pada tabel 10. Perhitungan nilai Service Quality (GAP) keseluruhan antara persepsi dan harapan pelanggan bertujuan untuk memberikan informasi seberapa besar tingkat kepentingan dan seberapa jauh peran kriteria tersebut dalam memberikan peningkatan kepuasan. Hasil perhitungan nilai Service Quality (GAP) keseluruhan antara persepsi dan harapan pelanggan dapat dilihat pada tabel 11.

Tabel 11. Nilai Service Quality (GAP) Keseluruhan

\begin{tabular}{|l|c|c|r|c|c|c|c|}
\hline \multirow{2}{*}{\multicolumn{1}{|c|}{ Dimensi }} & \multicolumn{2}{c|}{ Mean } & \multirow{2}{*}{ GAP } & \multicolumn{2}{c|}{ Fuzzy } & \multirow{2}{*}{ GAP } & \multirow{2}{*}{ Ranking } \\
\cline { 2 - 3 } \cline { 5 - 8 } & Harapan & Persepsi & & Harapan & Persepsi & & \\
\hline Reliability & 4,26 & 4,16 & $-0,100$ & 0,740 & 0,840 & 0,100 & 2 \\
\hline Responsiveness & 4,23 & 4,14625 & $-0,08375$ & 0,770 & 0,856 & 0,086 & 4 \\
\hline Assurance & 4,25 & 4,16 & $-0,09$ & 0,750 & 0,840 & 0,090 & 3 \\
\hline Empathy & 4,22 & 4,175 & $-0,045$ & 0,780 & 0,820 & 0,040 & 5 \\
\hline Tangible & 4,29 & 4,12625 & $-0,16375$ & 0,710 & 0,849 & 0,139 & 1 \\
\hline & & & & 0,750 & 0,841 & 0,091 & \\
\hline
\end{tabular}

Berdasarkan perhitungan nilai Service Quality (GAP) keseluruhan antara persepsi dan harapan pelanggan diatas menunjukkan bahwa semua nilai dari masing-masing dimensi bernilai positif yang artinya apa yang diharapkan pelanggan sudah sesuai dengan apa yang diperoleh pelanggan dari perusahaan penyedia jasa ojek online yaitu Grab dan Go-Jek.

\section{Kesimpulan}

Dari hasil penelitian dan dengan metode Fuzzy Service Quality yang dilakukan antara persepsi dan harapan yang didasarkan pada lima dimensi kualitas pelayanan yaitu Reliability (keandalan), Responsiveness (daya tanggap), Assurance (jaminan), Empathy (empati) dan Tangibles (bukti terukur), didapatkan bahwa secara umum dari masing-masing dimensi memiliki nilai GAP (kesenjangan) bernilai positif dikarenakan nilai persepsi lebih besar dari pada nilai harapan pelanggan. Dengan demikian dapat diartikan bahwa pelanggan puas terhadap pelayanan yang selama ini diberikan oleh pihak Grab dan Go-Jek namun masih perlu dilakukannya perbaikan supaya pelanggan tidak beralih ke model transportasi lainnya.

Perbaikan ini terutama harus difokuskan kepada dimensi empati walaupun sebenarnya dari segi profesionalitas usaha perbaikan demikian bisa jadi menimbulkan dilemma. Di satu sisi, profesionalitas mensyaratkan kinerja yang berbasis kompetensi artinya pelayanan diberikan atas hubungan timbal balik. Di sisi lain, menekankan empati apalagi berlebihan dalam profesionalitas pelayanan jelas bisa beresiko. Tidak dapat dipungkiri bahwa dimensi ini tampaknya lebih pada hubungan antar pribadi daripada dalam konteks profesionalitas pelayanan. Jika pun harus mengadopsi dimensi ini sebagai ukuran kepuasaan pelayanan, maka kebijakan yang perlu diambil diharapkan justru tidak menjadi halangan bagi profesionalitas tersebut. 


\section{Daftar Pustaka}

Arifin, M. A. M. K. Y. M. (2011). Dampak Keberadaan Transportasi On Line Terhadap Kondisi Sosial Ekonomi Transportasi Konvesional Di Kota Kediri. Jimek, 2(2), 168-181.

Azizah, A., \& Adawia, P. R. (2018). Analisis Perkembangan Industri Transportasi Online di Era Inovasi Disruptif (Studi Kasus PT Gojek Indonesia). Cakrawala - Jurnal Humaniora, 18(2), 149-156. https://doi.org/10.31294/JC.V18I2.4117

Fajar Nugraha, Zulfadhli, A. S. F. (2020). Dampak Perkembangan Industri Transportasi Online Terhadap Sosial Ekonomi Pengemudinya Di Kota Banda Aceh. 03, 345-351.

Fakhriyah, P. (2020). Pengaruh Layanan Transportasi Online (Gojek) Terhadap Perluasan Lapangan Kerja Bagi Masyarakat Di Kota Cimahi. Comm-Edu (Community Education Journal), 3(1), 34. https://doi.org/10.22460/comm-edu.v3i1.3719

Kartika, N. F. (2017). Implementasi Fuzzy - Service Quality Terhadap Tingkat Kepuasan Layanan Mahasiswa Implementation of Fuzzy - Service Quality for Student Service Level of Satisfaction. Jurnal Ilmiah SISFOTENIKA, 7(1), 38-49.

Ligoresi, R. R., Mola, S. A. S., \& Rumlaklak, N. D. (2017). Penerapan Metode Fuzzy Service Quality ( Servqual ) Untuk Menganalisa Kepuasan Pelayanan Pendidikan. Komputer \& Informatika, 5(2), 48 58.

Rimawati, E. (2016). pengaruh kualitas layanan terhadap kepuasan pelanggan stmik sinar nusantara surakarta. SINUS, 14(1), 55-66.

Sholikah, H., \& Iriananda, S. W. (2017). Analisis Kepuasan Pelanggan Travel Menggunakan Metode Fuzzy Service Quality. JOINTECS (Journal of Information Technology and Computer Science), 2(2), 5358. https://doi.org/10.31328/jointecs.v2i2.468

Widia Afriyuni, Rahmiati, M. R. L. (2019). Analisis Kualitas Pelayanan Dengan Menggunakan Metode Fuzzy-Servqual Pada Kantor Pos Pusat Kota Padang. 2(1), 18-26.

Widyarto, W. O., Djamal, N., \& Adhim, F. (2018). Analisis Kualitas Pelayanan Publik dengan Metode Fuzzy-Service Quality (F-Servqual) dan Index Potential Gain Customer Value (IPGCV). Jurnal Sistem Dan Manajemen Industri, 2(2), 101. https://doi.org/10.30656/jsmi.v2i2.769

Yunus, M., Soesilowati, E., Liesnoor, D., \& Arsal, T. (2019). Analisis Sistem Kerja Aplikasi Transportasi Online dalam Peningkatan Kinerja Driver. Seminar Nasional Pascasarjana 2019, 1039-1043. 